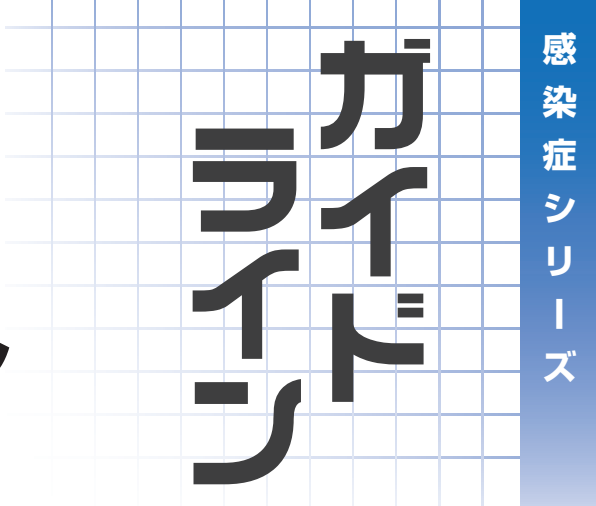

国立病院機構南岡山医療センター 呼吸器・アレルギー内科

\title{
Guideline for the treatment of acute exacerbations of COPD and chronic bronchitis
}

Yasushi Tanimoto

Department of Allergy and Respiratory Medicine, National Hospital Organization Minami-Okayama Medical Center

\section{はじめに}

日本感染症学会と日本化学療法学 会では，2001年に「抗菌薬使用の手 引」を，2005年に「抗菌薬使用のガ イドライン」を,また2011年に「JAID ／JSC 感染症治療ガイド2011」を刊 行している。そして本年 1 月に，両 学会が我が国の呼吸器感染症診療を 反映し，できるだけ $\mathrm{EBM} に$ 基いた $\lceil\mathrm{JAID} / \mathrm{JSC}$ 感染症治療ガイドライ ン一呼吸器感染症—」1) を公表し た。呼吸器領域における「JAID／ JSC 感染症治療ガイド2011」の改定 版にあたるものであるが, 呼吸器感 染症全般を網羅した最新の治療指針 となっている. 本稿ではこのガイド ラインの中から, 慢性閉塞性肺疾患 (COPD), 気管支拡張症や陳旧性肺 結核などの慢性呼吸器疾患における 気道感染症の治療ガイドラインに絞 って概説する。

\section{臨床症状と画像所見}

慢性呼吸器疾患の気道感染症ある いは感染性増悪とは, COPD, 気管 支拡張症, 陳旧性肺結核などの基礎 疾患の慢性安定期の状態から, 細菌

平成 26 年 6 月受理

干701-0304 岡山県都寉郡早島町早島4066

電話：086-482-1121

FAX : 086-482-3883

E-mail : tanimoto.yasushi@momc.jp
感染に伴い咳，膿性痰の増加ならび に膿性度の増強といった呼吸器症状 に加え，発熱ならびに息切れなどの 感染症状が新たに出現することをい う。検査成績では, 白血球や CRP な どの炎症反応が充進し, 血液ガス分 析でしばしば PaO2が低下する。持 続感染時は, 咳や痰の排出が継続し, 血液検査でも軽度の炎症反応がみら れることがある.このような場合は, 原則として抗菌薬を投与すべきでは なく, 感染の評価に喀痰のグラム染 色が有用である。

肺炎との鑑別をするために画像所 見が必要であり, 胸部X線写真で陰 影が認められないことを確認する。

肺気腫や気管支拡張症などの基礎疾 患を評価するために，また陰影を呈 する他疾患との鑑別のためにも CT も施行するのが望ましい.

\section{グラム染色と原因微生物}

喀痰が採取できる症例が多く,グ ラム染色は原因微生物の推定や持続 感染との鑑別に有用である。喀痰に
は多くの情報が含まれており，最も 重要な検体である。検体は抗菌薬投 与前に採取されるべきであり，早朝 起床時に採取されたものが理想的で ある。痰の膿性度は Miller \& Jones 分類 (表 1$)^{2)}$ が用いられるが，P 2 以上の検体であればグラム染色で原 因微生物を推定できる可能性が高 い.また，抗菌薬投与前に喀痰を必 ず感受性検査に提出しておく.

原因微生物としては, H.influenzae, P.aeruginosa, M.catarrhalis, S.pneumoniaeの頻度が高い. P.aeruginosa は持続感染している 場合が多いが, 臨床症状や検査成績 などから急性増悪と鑑別する必要があ る.他には, S.aureus や K.pneumoniae などを考慮する(表2 $)^{3,4}$.C.pneumoniae などの非定型病原体の関与やウイル スと細菌の混合感染も考慮する。

\section{治療}

治療の目的は, 臨床症状の改善, 再発の予防，次回の増悪までの期間 の延長ならびに肺組織へのダメージ

表 1 痰の膿性度 Miller \& Jones の分類 ${ }^{2}$
M 1：唾液, 完全な粘液痰
M 2 : 粘液痰の中に少量の膿性痰を含む
P 1：膿性部分が $1 / 3$ 以下の痰
P 2 : 膿性部分が $1 / 3 \sim 2 / 3$ の痰
P 3 : 膿性部分が $2 / 3$ 以上の痰 
表 2 主な原因微生物

\begin{tabular}{lll}
\hline \multicolumn{1}{c}{ 細菌 } & \multicolumn{1}{c}{ ウイルス } & \multicolumn{1}{c}{ 非定型病原体 } \\
\hline Haemophilus influenzae & Rhinovirus & Chlamydophila pneumonia \\
Streptococcus pnerumoniae & Parainfluenza & Mycoplasma pneumonia \\
Moraxella catarrhalis & Influenza & \\
Pseudomonas aeruginasa & Respiratory syncytial virus & \\
Enterobacteriaceae & Coronavirus & \\
Haemophilus haemolyticus & Adenovirus & \\
Haemophilus parainfluenzae & Human metapneumovirus & \\
Staphylococcus aureus & & \\
\hline
\end{tabular}

(文献 3,4 上り改変)

の抑止である. 適切な抗菌薬投与は 臨床症状を消失させるだけでなく， 呼吸機能の保持にも貢献できること が示されている ${ }^{5)}$. 一方, 不適切な 抗菌薬は予後の悪化に加え再発もさ せやすい。

我が国では, S.pneumoniaeや H.influenzae のマクロライド系薬 や $\beta$-ラク夕ム系薬に対する耐性化 が進んでいる。したがってこれらの 薬剤の使用は症例毎に考慮する。 $\beta-$ ラクタム系薬に比ベニューキノロン 系薬の有用性が報告されている。レ スピラトリーキノロンは原因微生物 全てに対して良好な抗菌活性を有し ており，第一選択である。抗菌薬の 投与期間は $5 \sim 7$ 日間程度で十分と されている。

\section{推奨される治療薬}

\section{Empiric therapy}

$\beta$-ラク夕ム系薬の有用性を支持 する報告も海外にはあるが，我が国 では, S.pneumoniae や H.influenzae のマクロライド系薬や $\beta$-ラクタム 系薬に対する耐性化が進んでおり P.aeruginosa も時折分離されるこ とから $\beta$-ラク夕ム系薬やマクロラ イド系薬の使用はリスクファクター のない症例に限定的に使用する。 $\mathrm{AZM}$ 徐放製剤は, 海外での比較試 験でニューキノロン系薬との同等性
が報告されている。しかしながら， 我が国ではマクロライド長期投与が 施行されている症例が多いため, 状 況が異なる。

\section{1 ）外来治療}

\section{(1) 第一選択}

(1) LVFX 経口 1 回500mg ・ 1 日 1 回

(2) GRNX 経口 1 回 $400 \mathrm{mg} \cdot 1$ 日 1 回

(3) MFLX 経口 1 回400mg ・ 1 日 1 回

(4) STFX 経口 1 回 $100 \mathrm{mg} \cdot 1$ 日 2 回 または 1 回 $200 \mathrm{mg} ・ 1$ 日 1 回(保 険適応外)

これら 4 薬片は推定される原因微 生物すべてに優れた抗菌活性を有し ており,第一選択薬として推奨される.

\section{（2）第二選択}

(1) CVA / AMPC 経口 (125mg/250 $\mathrm{mg}) 1$ 回 2 錠 $\cdot 1$ 日 $3 \sim 4$ 回(添 付文書最大 4 錠 / 日) (保険適応 外)

(2) SBTPC 経口 $(375 \mathrm{mg}) 1$ 回 1 錠 1 日 3 回

(3) AZM 徐放製剂経口 1 回 $2 \mathrm{~g} \cdot$ 単回

\section{2）入院治療}

(1) 軽症例

(1) CTRX 点滴静注 1 回 $2 \mathrm{~g} \cdot 1$ 日 1 回または 1 回 $1 \mathrm{~g} ・ 1$ 日 2 回

(2) LVFX 点滴静注 1 回 $500 \mathrm{mg} \cdot 1$ 日 1 回

(3) $\mathrm{SBT} / \mathrm{ABPC}$ 点滴静注 1 回 $3 \mathrm{~g}$ 1 日 $3 \sim 4$ 回
(2) 重症例 (P.aeruginosaを考慮す る.)

(1) MEPM 点滴静注 1 回 $1 \mathrm{~g} \cdot 1$ 日 $2 \sim 3$ 回

(2) DRPM 点滴静注 1 回0.5 $1 \mathrm{~g}$ • 1 日 3 回

(3) BIPM 点滴静注 1 回 $0.3 \sim 0.6 \mathrm{~g} \cdot$ 1 日 $3 \sim 4$ 回（添付文書最大 $1.2 \mathrm{~g} /$ 日)

(4) IPM $/ \mathrm{CS}$ 点滴静注1回 $0.5 \sim 1 \mathrm{~g} \cdot$ 1 日 $2 \sim 4$ 回（添付文書最大 2 $\mathrm{g} /$ 日)

(5) $\mathrm{TAZ} / \mathrm{PIPC}$ 点滴静注1回 $4.5 \mathrm{~g} \cdot$ 1 日 $3 \sim 4$ 回†

(6) PZFX 点滴静注 1 回500 1,000 $m g \cdot 1$ 日 2 回

(7) CPFX 点滴静注 1 回 $300 \mathrm{mg} \cdot 1$ 日 2 回

(8) CAZ 点滴静注 1 回 $1 \sim 2 \mathrm{~g} \cdot$ 1 日 $2 \sim 4$ 回（添付文書最大 4 $\mathrm{g} /$ 日）

(9) CFPM 点滴静注 1 回 $1 \sim 2 \mathrm{~g} \cdot$ 1 日 $2 \sim 4$ 回（添付文書最大 4 $\mathrm{g} /$ 日）

(10) CZOP 点滴静注 1 回 $1 \sim 2 \mathrm{~g}$ • 1 日 $2 \sim 4$ 回（添付文書最大 4 $\mathrm{g} /$ 日)

(11) $\mathrm{CPR}$ 点滴静注 1 回 $1 \sim 2 \mathrm{~g} \cdot$ 1 日 $2 \sim 4$ 回（添付文書最大 4 $\mathrm{g} /$ 日）

*症例に応じてアミノグリコシ ド系薬の併用を考慮する。 
(12) AMK 点滴静注 1 回 $200 \mathrm{mg} \cdot 1$ 日 2 回

(13) GM 点滴静注 1 回 $60 \mathrm{mg} \cdot 1$ 日 2 回

(14) TOB 点滴静注 1 回 $90 \mathrm{mg} \cdot 1$ 日 2 回

\section{2 . Definitive therapy}

\section{1 ) H.influenzae}

$10 \sim 20 \%$ 程度の頻度で $\beta$-ラク夕 マーゼを産生する株が認められ, $\beta$ ラクタマーゼ非産生アンピシリン耐 性株(BLNAR； $\beta$-lactamase negative ampicillin resistant) が20\%程度存在 する。従って, 薬剤感受性が不明の 場合は, 経口抗菌薬の第一選択は, ニューキノロン系薬となる. 薬剤感 受性が判明したら, 有効でかつ狭域 なものに変更する。注射薬では，ペ ニシリン系薬, $\beta$-ラクタマーゼ阻害 薬配合ペニシリン系薬，カルバペネ ム系薬, ニューキノロン系薬の順に 選択する。

\section{2 ) M.catarrhalis}

$\beta$-ラクタマーゼ産生菌がほぼ100 \%にみられる。経口抗菌薬は, マク ロライド系薬, $\beta$-ラクタマーゼ阻害 薬配合ペニシリン系薬, 第 $2 \cdot 3$ 世 代セフェム系薬，二ューキノロン系 薬の順に選択する。注射薬では, $\beta-$ ラクタマーゼ阻害薬配合ペニシリン 系薬, 第 $2 \cdot 3$ 世代七フェム系薬, ニューキノロン系薬, カルバペネム
系薬が良い選択となる。

\section{3 ) P.aeruginosa}

経口薬としては，ニューキノロン 系薬, 注射薬では, 抗緑膿菌セフェ ム系薬, モノバクタム系薬, カルバ ペネム系薬，ニューキノロン系薬を 選択する。本菌は菌株間の感受性が 大きくことなるので，培養検査結果 など参考にして薬剤選択を行う。

\section{4 ) S.pneumoniae}

経口薬としては,ペニシリン系薬, ニューキノロン系薬の順に選択す

る。耐性菌のリスクがある患者に対 しては, LVFX や GRNX といったい わゆるレスピラトリーキノロンを選 択する，注射薬としては，ペニシリ ン系薬や CTRX な゙が選択される が，重症例に対してはカルバペネム 系薬を考慮する。

\section{5 ) S.aureus}

メチシリン感受性黄色ブドウ球菌 （MSSA）を想定して治療薬を選択 する。 $\beta$-ラクタマーゼ阻害薬配合ペ ニシリン系薬，第 $1 \cdot 2$ 世代セフェ ム系薬，カルバペネム系薬などが選 択される。メシリン耐性黄色ブド ウ球菌（MRSA）と判明した際は, 抗 MRSA 薬を選択する。

\section{6 ) K.pneumoniae}

第 2 世代セフェム系薬が第一選択 となる。第二選択薬としては， $\beta$ ラクタマーゼ阻害薬配合ペニシリン
系薬，第 $2 \cdot 3$ 世代セフェム系薬， カルバペネム系薬，ニューキノロン 系薬が挙げられる。

\section{文献}

1）一般社団法人日本感染症学会, 公益社 団法人日本化学療法学会 JAID/JSC 感染症治療ガイド・ガイドライン作 成委員会 呼吸器感染症 WG：委員会 報告 JAID/JSC 感染症治療ガイドラ イン一呼吸器感染症一。感染症誌 (2014) 88, 1-109.

2 ) 日本呼吸器学会呼吸器感染症に関す るガイドライン作成委員会：呼吸器 感染症に関するガイドライン 成人気 道感染症診療の基本的考え方, 日本呼 吸器学会, 東京 (2003).

3 ) Sethi S, Murphy TF : Infection in the pathogenesis and course of chronic obstructive pulmonary disease. N Engl J Med (2008) 359, 2355-2365.

4) Hui DS, Ip M, Ling T, Chang SC, Liao CH, Yoo CG, Kim DK, Yoon HI, Udompanich V, Moqmeud S, Muttalif R, Salleh AM, et al. : A multicentre surveillance study on the characteristics, bacterial aetiologies and in vitro antibiotic susceptibilities in patients with acute exacerbations of chronic bronchitis. Respirology (2011) 16, 532-539.

5 ) Adams SG, Melo J, Luther M, Anzueto A: Antibiotics are associated with lower relapse rates in outpatients with acute exacerbations of COPD. Chest (2000) 117, 13451352. 